\title{
Merleau-Ponty's Phenomenology of Sympathy
}

\section{MARTIN J. MATUSTIK \\ Fordham University}

Merleau-Ponty never wrote a phenomenology of sympathy. But his use of sympathy in accounting for human relationships parallels in intent and manner his treatment of perception in the Phenomenology. 1 In addressing the paradox of alterity, he draws an analogy between perception and sympathy: just as perceptual consciousness founds intersubjective thematic experience, in the same way pre-personal sympathy accounts for the possibility of affective intersubjective relations.

Just as my body, as the system of all my holds on the world, founds the unity of the objects I perceive, in the same way the body of the other--as the bearer of symbolic behaviors and of the behavior of true realitytears itself away from being one of my phenomena, offers me the task of a true communication, and confers on my objects the new dimension of intersubjective being or, in other words, of objectivity (PrP in PoP 18).

Along with operative intentionality-awareness of the existential, lived horizon against which we thematize the world-the primordial affect of sympathy in early ontogenesis and in adulthood exercises primacy over thematic and deliberate relations of sympathy and antipathy.

Just as the perception of a thing opens me up to being, by realizing the paradoxical synthesis of an infinity or perceptual aspects, in the same way the perception of

1 Abbreviations for cited texts by Maurice Merleau-Ponty-

AD: Adventures of the Dialectic, trans. Joseph Bien (Evanston: Northwestern University Press, 1973).

PP: Phenomenology of Perception, trans. Colin Smith (London: Routlege and Kegan Paul, 1962).

PoP: The Primacy of Perception, trans. Silverman, ed. James M. Edie (Evanston: Northwestern University Press, 1964).

PrP: "The Primacy of Perception and Its Philosophical Significance," in PoP: $12-42$.

RO: "The Child's Relations with Others," in PoP: 96-155.

SN: Sense and Nonsense, trans. Herbert L. Dreyfus and Patricia A. Dreyfus (Evanston: Northwestern University Press, 1964).

VI: The Visible and the Invisible, trans. Alphonso Lingis, ed.

Lefort (Evanston: Northwestern University Press, 1968). 
the other founds morality by realizing the paradox of an alter ego, of a common situation, by placing my perspectives and my incommunicable solitude in the visual field of another and of all the others (PrP in PoP 26).

Even though there is a direct analogy between the primacy of perception in cognition and the primacy of sympathy for affective relations, the parallelism breaks down when we compare the thetic acts of judgment with explicit acts of sympathy in love and dialogue. The relation between perception and cognition is a founded matter of fact, in pre-thematic and thetic acts of understanding alike. Nevertheless, the need to realize sympathy in responsible and deliberate acts is an ethical imperative. Even though master and slave relations in their violence presuppose the horizon of sympathy, an achievement of love and dialogue is not guaranteed by this latent affective horizon.

I argue that Merleau-Ponty's phenomenology of love and dialogue correctly depicts pre-personal sympathy as the ontology of ethical life. But he is not always careful in making the distinction between the ontological and the ethical level of analysis. One can thematize the ethical primacy of sympathy over adult conflictual relations only when the operative conditions of love and dialogue are fulfilled also in thematic and deliberate acts. Still, his phenomenology of sympathy can provide a ground-work for communicative and existential ethics when the following three stages in human development are kept descriptively and critically distinct: the legitimate privileging of pre-personal sympathy in founding and sustaining alterity and self-identity in early ontogenesis and in adulthood; ordinary and pathological failures in sustaining self-identity and intersubjective relations in conflict, jealousy, and various mental disturbances; and the thematic and deliberate recovery of primordial sympathy as the founding pole in an adult sympathy of love and discourse.

This paper will explicate Merleau-Ponty's philosophical use of operative intentionality and critically examine whether and how his thesis of the primacy of sympathy can by itself account for alterity. First, I will lay out the rationale underlying the distinction between operative and thetic intentionality, on the one hand, and that between primordial precommunicative sympathy in children and the adult sympathy of love, on the other hand. Secondly, I will turn to Merleau-Ponty's commentary on Wallon's study of the mirror-stage of childhood development in which the former argues that the attitude of primordial sympathy and not desire or jealousy constitutes the operative condition of the possibility of adult relations. 2

2 Henri Wallon, Les Origenes du caractere chez l'enfant, 2nd ed. (Paris, 1949). Cf. Jacques Lacan's psychoanalytical reading of the mirror-image of the child development in his commentary on Wallon (Écrits: A Selection, 
Thirdly, I will confront Merleau-Ponty with the following question: Given the ontological primacy of sympathy in human ontogenesis, in what sense is it legitimate to speak of its ethical primacy in adult intersubjectivity? How does his argument from operative intentionality and precommunicative sympathy contribute to the possibility of communicative and existential ethics?

\section{INTENTIONALITY AND THE PARADOX OF ALTERITY}

Husserl's clue to the primacy of operative, fungierende intentionality over reflective, thematic consciousness becomes the vehicle of Merleau-Ponty's philosophical argument for the primacy of sympathy over the role of constituting intentionality in founding and sustaining alterity.3

In our opinion Husserl's originality lies beyond the notion of intentionality; it is to be found in the elaboration of this notion and in the discovery, beneath the intentionality of representations, of a deeper intentionality, which others have called existence. (PP 121, n. 5)

Merleau-Ponty differentiates the thematic intentionality of acts or of understanding from operative intentionality. The former notion of intentionality relates to the world cognitively and in that sense exhibits thematic and constitutive consciousness. The latter as existential and not conceptual or objectifying carries my embodied meaning, my incarnation. Ricoeur notes that the theorem of operative intentionality has implications for the phenomenology of the body. "When asked how it is possible for a meaning to exist without being conscious, the phenomenologist replies: its mode of being is that of the body, which is neither an ego nor a thing of the world."4

trans. A. Sheridan (New York: W.W. Norton, 1977], pp. 1-7). Merleau-Ponty comments both on Wallon's study of the mirror-stage and Lacan's paper.

3 On fungierende Intentionalitat, cf. Edmund Husserl, Vorlesungen zur Phanomenologie des inneren Zeitbewußtseins, and Formale und transcendentale Logik, cited by Merleau-Ponty, PP 418, n. 1; also Paul Ricoeur, Freud and Philosophy: An Essay on Interpretation, trans. Denis Savage (New Haven: Yale University Press, 1970), pp. 375-418 and the index for Lacan and Merleau-Ponty.

4 Ricoeur, Freud, p. 382. Ricoeur questions the ambiguity of MerleauPonty's early treatment of operative intentionality: "What is this intentionality which would like to protect itself from the idealistic implications of Husserlian phenomenology and which nonetheless 
Not Husserl but already Descartes and Kant directed the attention of modern philosophy to constitutive consciousness and the intentionality of acts (PP ix, xvii-xviii, 121, n. 5). The intentionality of acts explains that the unity of consciousness is not possible without the simultaneous apprehension of the unity of the world. 5 All consciousness occurs only as consciousness of something. The temporal determination of my inner perceptions is bound up by the outer perception of existing things in space. I come into being as consciousness only in relation to possible intentional objects (PP xvii, 121). Consciousness is conceived of as a network of intentional relations between the understanding subject and the object. Consciousness is "a pure meaning-giving act" (PP 121). Through the thematic acts I know my being in the world as a constituting, that is cognitive, relation of my conscious subjectivity to the intentional object. A methodology of reduction which only works out of the theorem of thematic intentionality must remain within the philosophy of consciousness, which is to say, a subject-centered phenomenology.

Merleau-Ponty does not jettison reflective phenomenology and the acts of thetic intentionality. Nevertheless, he limits his inquiry to the conditions of the possibility of thetic, constituting consciousness. In fairness to him, we should not interpret the ontological concerns in his phenomenological project as a denial of critical philosophy but rather as an exploration of the implicit presuppositions of phenomenology, of the ambiguity in phenomenological foundations. 6 His inquiry into the conditions of the possibility of one's cognitive relation to the world leads him to

remains dependent on a philosophy of consciousness and of the subject? What is this world which we do not constitute as reflective consciousness but which we indeed seem to project as a tacit or bodily cogito?" [Foreword in Gary B. Madison, The Phenomenology of Merleau-Ponty (Athens, Ohio: Ohio University Press, 1981), p. xv.J

5 Cf. Kant's Critique of Pure Reason trans. Norman Kemp Smith (New York: St. Martin's P, 1965), "Refutation of Idealism" and Preface B.

6 There is another question about the thesis of the primacy of sympathy which I address in the sequel to this paper (cf. * below): Can archeology of operative intentionality be foundation of a sufficiently critical phenomenology? Does Merleau-Ponty offer a hermeneutic of suspicion cognizant of the difference between an ambiguity of phenomenological reduction and an ambivalence of the unconscious? Cf. James L. Marsh, "Dialectical Phenomenology: From Suspension to Suspicion," Man and World 17 (1984): 121-41 and Post-Cartesian Meditations: An Essay In Dialectical Phenomenology (New York: Fordham University Press, 1988); cf. my review-article of Marsh "Transcendental-Phenomenological Retrieval and Critical Theory" in Method: Journal of Lonergan Studies (March 1990): 94-105. Madison, The Phenomenology, p. 164; Ricoeur, Freud, passim. 
Husserl's clue about operative intentionality. Operative intentionality and temporality must be the prius of all cognitive comportment in the world (PP 418). According to the deeper (PP 121), broadened (PP xviii), new (PP . 243) and true (PP 446) notion of intentionality, the unity of the world is not primarily posited or constituted cognitively but originates in a lived, antepredicative and existential unity.

In arguing for the primacy of operative intentionality which founds the cognitive judgment of perception, Merleau-Ponty critiques idealism for privileging thetic truth over one's existential being-in-theworld (PP 418, ix, xii-xiii, xvii-xviii). In his polemic against idealism and empiricism, he strives for a descriptive non-duality. But the thesis of the primacy of latent, pre-reflective intentionality is not a new form of longing for the noumenal, the pre-reflective in-itself, characteristic of idealism. This thesis suggests that my life world which pivots back and forth between the pre-reflective as such and the constitutive acts of knowledge and deliberation is the originator of the derived thematic distinction between my constitutive subjectivity and intentional objects. Merleau-Ponty does not jettison the proper use of the philosophical distinction between the thematic and the operative but assumes concrete posture within the life world which allows one to make this distinction legitimately. Idealist and empiricist points of departure neglect, truncate and alienate my lived and embodied existence. Operative intentionality, he argues, is a primary and founding dimension of one's being-in-the-world; although not an absolute foundation (we take it up as an already founded existence) it is originary "in the sense that the originated is presented as a determinate or explicit form of the originator, which prevents the latter from reabsorbing the former..." (PP 394). In his later work, Merleau-Ponty preserves the twoterm intentionality analysis but grounds the distinction not in the life world but within a non-dualistic ontology of Being.

The limit discovered in attempting Husserl's phenomenological reduction, i.e. that we never have apodictic knowledge, implies for Merleau-Ponty not only the primacy of operative over thetic intentionality but also the primacy of ontology over phenomenology: an explicit intentionality of cognitive acts presupposes an implicit intentionality within being" (VI 244).7 Phenomenology requires an ontology; this requirement becomes fully explicit only in the later Merleau-Ponty. 8 His argument from operative intentionality suggests that there is an implicit ontology in his early work. 9 Since existential phenomenology already implies an

7 Merleau-Ponty argues for the impossibility of complete reduction also in the context of affective appropriation of the specular image in childhood development. Cf. Il below.

8 VI 140, 175-76, 200, 231, 238-39, 243-44, 254, 267, 270. 
ontology, he argues also in his social phenomenology for the ontological primacy of primordial sympathy over the thetic and deliberate human relationships.

The two notions of intentionality bear directly on the paradox of alterity (PP xii). Just as Merleau-Ponty's overall phenomenological argument is for the founding function of operative intentionality over cognitive intentionality, so also here he reasons for the affective and epistemological primacy of primordial sympathy over the dialectic of sympathy and antipathy in deliberate acts. The thesis of the primacy of sympathy has an ontological precedence over the developmentally later dialectic of alienating gazes. Just as the phenomenology of perception begins with a rigorous descriptive account of experience which founds our thetic grasp of the lived world, so also the phenomenology of sympathy situates itself within the conditions of the possibility of thematically and deliberately being sympathetic or antipathetic to others in adult relations (PP 425).10 He considers as derivative any phenomenology which takes its beginning from constitutive consciousness or its affective equivalent, namely the master-slave desire of recognition. Just as thetic consciousness is only a founded and thus derived term understandable merely on the background of the pre-thematic primacy of perception, so also the dialectics of desire are for him derivative modes of intersubjectivity--intelligible because of the primacy of pre-personal sympathy.

Here a distinction must be drawn between the primordial, precommunicative sympathy of syncretic sociability in childhood and the adult sympathy of love. Only love is "a genuine sympathy" because the adult me, while remaining distinct from the adult alter, is capable of deliberately transgressing the known limits of identities (RO in PoP 120). Adult sympathy can never be a simple return to childhood; what separates the adult me from the primordial me is an intervening and decisive differentiation of ego-identity and alterity. "The initial sympathy rests on the ignorance of oneself rather than on the perception of others, while adult sympathy occurs between "other" and "other"; it does not abolish the differences between myself and the other"(ibid.). It is obvious that Merleau-Ponty is not arguing for the primacy of love in same manner as he argues for the primacy of primordial sympathy: while primordial

9 "...in order to see the world and grasp it as paradoxical, we must break with our familiar acceptance of it ... from this break we can learn nothing but the unmotivated upsurge of the world [later: the upsurge of Beingl. The most important lesson which the reduction Iphenomenological selfappropriation] teaches us is the impossibility of a complete reduction" (PP xiv).

10 Cf. Ricoeur, Freud, pp. 386ff. I am articulating Merleau-Ponty's argument for the primacy of sympathy as the condition of the possibility of even the fall into antipathy. 
sympathy, as a theory of human intersubjective nature, is the condition of the possibility and impossibility of love, sympathy has solely an imperative and ethical but not ontological primacy over the failure to love.

To sum up: if we take Merleau-Ponty's phenomenology of love as a clue to his position on alterity, then we can safely conclude that he offers neither a causal explanation of adult maturity nor an alternative cognitive explanation (RO in PoP 96f.). The thesis of the primacy of sympathy does not privilege 'innocent' childhood over adult forms of interaction. The operative intentionality organizes both the world of the child and of the adult.

In his argument for the primacy of perception and sympathy, Merleau-Ponty returns to the paradox of intersubjectivity in Husserl's Cartesian Meditations (V, par. 44, 55, 56): How can I constitute myself and the alter in me? In this reappropriation of the paradox he addresses Husserl's thesis in The Crisis of European Sciences, that "[t]ranscendental subjectivity is a revealed subjectivity, revealed to itself and to others, and is for that reason an intersubjectivity" (PP 361, xiii). The problem of the experience of others appears because I must account for the possibility of four perspectives-my view of myself and the alter's of herself, my view of the alter and her of me--in order to explicate genuine alterity (PP xii, 373, 432, 448, PoP 115f.). Either the other is a constituting consciousness, and I myself am neither a constituting consciousness nor a subject for myself; or I constitute the alter, and thus he is not himself a constituting subject and not a true alter-ego. The paradox of constitution is that both the ego and the alter figure under the perspective of the for oneself and of the for others, but these cannot be arbitrarily juxtaposed.

Merleau-Ponty does not object to the distinction between operative and thematic consciousness, between primordial and deliberate sympathy. The distinction is fine as it stands, but it is useless in what Merleau-Ponty sets out to investigate. We should not infer that he judges all objectification, pertaining to the thematic intentionality of acts and to the deliberate posture towards the alter, as self-alienating or violent against the other. He offers different reasons for the shift in the manner of his analysis: he argues against constitutive consciousness as that level on which phenomenological analysis ought to focus. Because of the failure to account for the primacy of perception and of sympathy, idealists and empiricists have truncated, neglected and alienated the life-world as the sole theater of self-identity and alterity. Merleau-Ponty shifts the level of inquiry from constitutive consciousness to an 'archeology' of a prethematic, operative field of intersubjectivity. 11

11 Cf. Bernard Lonergan, The Subject (Milwaukee: Marquette UP, 1968); Collection, Vol. 4 of Collected Works of Bernard Lonergan (Toronto: $U$ of Toronto P, 1988), p. 211ff. and Marsh's Post-Cartesian Meditations, chap. on objectivity. 
Before thematizing the difference between alienation (e.g. in jealousy) and legitimate objectification (e.g. in greeting), he inquires into the conditions of the possibility of non-alienating objectification.

I must be the exterior that I present to others, and the body of the other must be the other himself. This paradox and the dialectic of the Ego and the Alter are possible only provided that the Ego and the Alter Ego are defined by their situation... that at the very moment when 1 experience my existence-at the ultimate extremity of reflection-I fall short of the ultimate density which would place me outside time, and that I discover within myself a kind of internal weakness standing in the way of $\mathrm{my}$ being totally individualized... (PPxii).

This 'internal weakness' betrays the pre-existing intersubjective bond of operative intentionality, i.e. primordial sympathy, that defines and founds both the for-oneself and the for-others.

[I]n sympathy...I can perceive another as bare existence and freedom as much or as little as myself. The-otheras-object is nothing but an insincere modality of others, just as absolute subjectivity is nothing but an abstract notion of myself. I must... in the most radical reflection, apprehend around my absolute individuality a kind of halo of generality or a kind of atmosphere of 'sociality'....My life must have a significance which I do not constitute. (PP 448)

Sympathy, love, lived existence in the world all express the instituted, hermeneutically given significance which I do not constitute; they form my ego-identity and a field in which I can thematically and deliberately take up relations with the other. For Merleau-Ponty, the paradox of intersubjectivity can be resolved only in the shift of analysis from the abstract subject as object and corresponding derived modalities of alterity to an existential concretion of the subject as subject and its corresponding phenomenology of primordial sympathy.

\section{THE THESIS OF THE PRIMACY OF SYMPATHY}

We have seen how the paradox of intersubjectivity appeared to a representational consciousness. I can't represent to myself how my alter feels her body; she can't represent herself in the same manner in which I constitute myself (RO in PoP 114). To account for the genuine foundation of inwardness and alterity, Merleau-Ponty reformulates the function of 
imitation, mimesis, in non-representational terms. "To imitate is to perform a gesture in the image of another gesture..." (RO in PoP 116). The phenomenology of sympathy explains how the ego takes up the postural and embodied attitude of the alter through non-representational mimesis of gestures. Mimesis is "that attitude whereby I assume the gestures, the conducts, the favorite words, the ways of doing things of those whom I confront" (RO in PoP 145). We can substitute our posture for that of the alter through gestures because the body carries the competence for "meditation," i.e. "the inward formulation of gestures" (RO in PoP 146). In mimesis one lives the gap between the inner and outer, inwardness and alterity. Mimesis is the correspondence between my perception of the alter and my motor behavior. But the transfer of the attitude of another to me is not a simple analogy (PP 352).

My "psyche" is not a series of "states of consciousness" that are rigorously closed in on themselves and inaccessible to anyone but me. My consciousness is turned primarily toward the world, turned toward things; it is above all a relation to the world.... Thus it is in...the manner in which the other deals with the world, that I will be able to discover his consciousness (RO in PoP 116-17).

Just as my consciousness of my own body is a corporeal, postural scheme, so also taking the attitude of the alter involves primarily a transfer of bodyintentions. What is transferred mimetically are not the representations of the alter through constitutive consciousness but a pre-communicative level of intersubjectivity. 12 "[T]he other's intentions somehow play across my body while my intentions play across his" (RO in PoP 119). MerleauPonty concludes that we can't account for alterity if the ego and the alter claim "an absolute originality in relation to the other that confronts it" (ibid.). Pre-communication is not yet communicative and existential ethics but it explicates how I can live my intentions in the gestures and facial expressions of others and their will in my body.

To give an example of non-thematic mimesis: a phenomenology of the smile is at once a phenomenology of perception and of sympathy. When I smile, "...I live in the facial expressions of the other, as I feel him living in mine" (RO in PoP 146.). According to the combined thesis of the primacy of perception and sympathy, perceptual consciousness founds my cognitive and deliberate self-appropriation and my comportment to the world and the alter. Yes, the smile is perceived, but the perceived smile

12 Merleau-Ponty reinterprets not only mimesis but also Husserl's pairing or coupling and intentional transgression. "In perceiving the other, my body and his are coupled, resulting in a sort of action which pairs them" (PoP 118). Cf. III below. 
need not be necessarily known as a thetic act of deliberate sympathy. It is cognitively apprehended only when one lover smiles at the other to communicate love or when the alter refuses to smile back.

Merleau-Ponty argues that humans emerge from anonymous collectivity into a segregation of individuals; but segregation is never a fully completed process. Because, as a child, I begin in an ambiguous situation in which I know neither myself nor the alter, but live in both, I carry my "primordial me" as my inward weakness into adulthood (ibid., PP xii). My primordial weakness is neither egocentrism (Cartesian anxiety is not one's originary problem) nor the desire to be desired (the struggle for recognition is not my first dilemma) but rather syncretic sociability.

Merleau-Ponty carries out this argument, first, in what we have followed in the thesis of the primacy of perception as a critique of idealism and empiricism. Secondly, he argues by offering counterproofs from the cases of developmental pathologies. These strategies show how operative intentionality and primordial sympathy are presupposed in human desires, in thetic acts and in deliberate struggles for recognition. Primordial sympathy or syncretic sociability is his philosophical figure of operative intentionality when it comes to the treatment of alterity. I will follow with an example.

The pathological case of Schneider does negatively certify the thesis of the primacy of perception and sympathy. In his failure, Schneider fits the idealist and the empiricist accounts of our comportment toward others and to the world; if the idealist and the empiricist epistemologies are the measure of truth, then the world is as Schneider perceives and constitutes it. His problem is that he lacks operative intentionality and can neither pattern and live through his actions nor find unity in the world (PP 109, 133, 136, 179, 187, 282). Does he suffer from the Cartesian or the Humean disease on the level of constitutive consciousness and sensing? Is he the slave of passions? No, he suffers from damage in motoric and gestural competencies. He can't coordinate through non-representational mimesis his motor activity with posture and the gestural dimension of expressivity. He can't live in his speech because of the breakdown on the level of primordial sympathy. He lacks the "intentional arc" which grounds all conceptual and thetic unity (PP 136). Because he does not suffer the Cartesian or the Humean predicament, but only appears to uphold the epistemological antinomies of idealism and empiricism, his case functions as a counter-proof for the thesis of the primacy of perception and the primacy of sympathy.

The above example of Merleau-Ponty's manner of proceeding in no manner implies a reduction of the thematic intentionality of acts, and of adulthood, to operative sympathy in children. His concern isn't that there is something wrong with constitutive consciousness. Schneider's case demonstrates that operative intentionality and sympathy are the conditions of the possibility of constitutive intersubjective existence. 
Merleau-Ponty can argue for the primacy of primordial sympathy without illegitimately privileging the child because he supports his case against idealism and empiricism by developmental studies and at the same time offers counterproofs from an existential analysis of adult pathologies. Rather than multiplying his explanatory categories, he utilizes the argument from operative intentionality across the board:

[T]he life of consciousness-cognitive life, the life of desire or perceptual life-is subtended by an intentional arc' which projects round about us our past, our future, our human setting, our physical, ideological and moral situation, or rather which results in our being situated in all these respects. It is this intentional arc which brings the unity of the senses, of intelligence, of sensibility and motility. And it is this which 'goes limp' in illness (PP 136).

It is within Merleau-Ponty's focus on the primacy of operative sympathy that we need to set his interpretation of the specular drama of the differentiation between the 'primordial me' and the alter. Only thus we can purchase some understanding on why the phenomenology of sympathy takes precedence over the dialectic of desire in his model of alterity.

Even though the child's consciousness of its own body develops prior to the perception of the alter, the child is unable to privilege itself over the alter (RO in PoP 120). A six month old child will begin to explore one hand with the other (RO in PoP 123). These explorations allow for the initial differentiation between the interoceptive and the exteroceptive senses of one's body, between the touched and touching. Likewise first reactions to the alter are not visual but are shot through with the child's own introceptive data (RO in PoP 124f.). The child's own hand appears equally as foreign as that of the alter.

Research shows that there is a difference between animals and children in their reactions to the specular image of their own body in the mirror. A duck whose mate dies sits in front of a window pane where his specular image simulates the lost mate. The image is for the duck the lost animal, and the duck completes himself via this supplement, an imprint in the pane (RO in PoP 126). In the same fashion dogs react with fear to their own mirror-image and will not grasp its symbolic function. Similarly chimpanzees fail to acquire the symbolic meaning of the mirror-image as their image. A chimpanzee might pass his 'hand' behind the mirror and be 'disappointed' that there is nothing behind it, but he doesn't recognize himself in the mirror (RO in PoP 127). The six month old child, unlike the animal, will go through a process of differentiation of his own specular image from others. An eight month old child will act surprised when she sees herself in the mirror, but she does not yet possess the symbolic notion 
of her specular image. It is harder for the ego to grasp its own specular image before the mirror-image of the alter. The child can recognize the father in a mirror and smile at his image. The phenomenology of the smile, based on the thesis of the primacy of sympathy, can account for this incident. But even here the child does not thematically constitute this image as a symbol of the father. When the father speaks, the child turns from the mirror-image of the father to him and is astonished.

Why is it more difficult to apprehend one's own specular image than the one of the alter? Why does anonymous alterity precede a genuine differentiation of the ego from the alter? Merleau-Ponty argues, first, that the mirror is the only locus where I can initially see my own body as a totality; but I take myself as being here where I locate myself interoceptively (RO in PoP 129). Now the mirror locates me neither interoceptively nor exteroceptively-as when my right hand touches my left hand. Secondly, I can be seen, on the one hand, only where I also feel myself interoceptively. But, on the other hand, only in the mirror can I see myself as a whole. I must reconcile this paradox through a displacement of the mirror-image, "bringing it from the apparent or virtual place it occupies in the depths of the mirror back to ... (myself) whom ... [I] identify at a distance with ... [my] introceptive body" (RO in PoP 129). The child facing his mirror-image finds himself doubled; he believes that his specular image, unlike the image of his parent, is his real double (ibid.).

To sum up: the human developmental process follows the reverse course of the Cartesian articulation of beginnings; my self-certainty of myself is the least and last of my certitudes. In one year the child emerges from a pre-communicative stage of non-differentiation into the specular world. She learns, first, to differentiate the parental image from the actual parent and, later, the specular image of herself from her actual self. But this latter step requires the reduction of the specular image, which the child takes for her real double, into the symbolic function of the specular image (RO in PoP 133). Merleau-Ponty shows the impossibility of a complete reduction of the specular image to the general conceptual level (RO in PoP 133). The specular drama reveals the ontological, if not a psychoanalytical, limit of Husserl's phenomenological reduction (PP xiv). The reduction of the mirror-image occurs not primarily as thematic and deliberate phenomenon; rather I acquire this reduction through a lived experience, sympathetic co-existence with others. The reduction means that child must return the specular image of herself to her body. Through an ideal notion of space she has to reduce that space which clings to the specular image and return it to her own introceptive sense of the corporeal posture. But the child's apprehension of the mirror-image isn't fully reduced to the conceptual and symbolic meaning it later assumes under the ideal form of space. In this lived inter-world, we don't have yet a pure 
egology or sociology of intersubjective selfhood.13 Existential analysis only clarifies the operative conditions of the possibility of perception, desire, self-identity and alterity.

Merleau-Ponty dissents from Wallon (Kant and early Husserl) who considers the act of reduction of the specular image as primarily a work of the intellect and from Lacan who explicates the role of the mirrorimage through one's unconscious identification with the alter (RO in PoP 139). Merleau-Ponty denies that cognitive reduction and the psychoanalytics of desire are fully explanatory of intersubjectivity. He takes the constituting function of thetic intentionality and conflictual relations, like jealousy, to be results of the development beyond syncretic sociability. Against Wallon and Lacan, he argues that we actually perceive ourselves in two different places. With Lacan, he agrees that affective significance is more significant than cognitive reduction in development of self-identity and intersubjective relations. Reduction of the specular image is not primarily a thetic act but "a synthesis of coexistence with others" (RO in PoP 140). This original sympathy with others, "the relation of 'reciprocity"' stands for what we call intelligence (ibid.). The "ubiquity of the body" which the child has to tackle in its confrontation with the specular double is the ground where alterity must be worked out (RO in PoP 139).

\begin{abstract}
The child's problem is not so much one of understanding that the visual and the tactile images of the body-both located in two points in space-in reality comprise only one, as it is of understanding that the image in the mirror is his image, that it is what others see of him, the appearance he presents to other subjects.... (RO in PoP 140)
\end{abstract}

This ubiquity of the body is not strictly real but only intentional (PP 331). But why are adults amused by the presence of "a quasi intention" when they see themselves in a mirror, a photograph or a painting (RO in PoP 132)? Wallon's cognitive reduction and simple socialization of the specular drama explains neither our mature adult behavior nor pathologies. One's image retains the halo of sacred presence, the quasipresence of one's person even for the adult. In my mature adult selfrelation, I can reflect and analyze my image which was hastily drawn as a sketch by a Montmartre street artist. I am not this sketch. But I can find

13 Cf. John O'Neill "The Specular Body: Merleau-Ponty and Lacan on Infant Self and Other" Synthese 66 (Fall 86), p. 204: "Yet it is only from this ground of anonymous intersubjectivity-not yet ego, not yet alter-that he can experience the generics of a bodily and personal self in a world similarly incorporated." 
myself animated by the real resemblance which asks for my belief, I can be amused (RO in PoP 132). I cling to the sketch even though I 'know' that it is not really me. The sketch is not very good. It's kitsch. But my friend might hesitate to step on it. Stepping on my imaged-face would involve her in an act of aggression. We are two adults and not Wallon's or Lacan's or Merleau-Ponty's experimental babies. But we can't simply shake off the sense that the sketch is not just a reflection of the incarnate me. I can suspend the sketch-image at a distance, but my reflective and analytical thematization will not be a clear-cut reduction (RO in PoP 133).

Even though the mirror-image loses its spatiality. when the child reaches one year, the impossibility of a total reduction of the specular drama surfaces when symbolic and constitutive consciousness is in difficulty. Pathological cases reveal the nature of the child's original belief that one can occupy several spaces at once (RO in PoP 129). We find this notion in dreams, in hypnosis, in dying and drowning people. Apraxics cannot spatially co-ordinate their movements with objects before the mirror; also their function of mimesis is disturbed in simple imitation of the alter's movements in front of them (RO in PoP 130). If the reduction of the specular image into one's interoceptive self-identity were complete, if in fact thetic intentionality were constitutive of self-identity and alterity, then these cases could not be used as counterproofs.

In the commentary on Wallon's study of infants' reactions to their mirror-image, Merleau-Ponty does not argue for a return to the childhood world but for a paradigm of adult maturity (RO in PoP 154f.). In the last two pages of his commentary, Merleau-Ponty discusses freedom in the context of adult loving (also PP 378, 381, 434ff). "To love is inevitably to enter into an undivided situation with another" (RO in PoP 154). In love I am torn away from my solitude and become mutually mediated with the alter. "[T]o be joined with someone else is...to live her life, at least in intention. To the very extent that it is convincing and genuine, the experience of the other is necessarily an alienating one" (ibid.). This sense of 'alienation' is evoked by risk, insecurity and doubt because in love there occurs a legitimate dispossession of the ego by the alter. The counter-example is an adult or a child who desires clear and distinct proofs of the other's affection: the adult only imprisons his desire to be desired by the alter in his absolute lone ego and the alter in the immediacy of desire (RO in PoP155).

Because the demand of proof represents the want of a total reduction of the other to an object, this illegitimate dispossession fails not only loving and dialogue but also freedom. Here Cartesianism and diehard empiricism betray all lovers. Whereas love dispossesses the ego for the sake of preserving alterity of the loved one, the attitude of sheer desire is fueled by violence towards itself and the alter. The lack of generosity and trust surfaces in every desire for a world free from risk.

Since there are no Cartesian or empiricist proofs of love apart from lived experience, love and reciprocal discourse heighten this risk to 
self-identity. The risk discloses an 'internal weakness' (PP xii) and insecurity within one's incomplete individuation. Just as the primacy of perception is Merleau-Ponty's "remedy to skepticism and pessimism," so also with the thesis of the primacy of sympathy he denies the Sartrean verdict that human sympathy is an illusion.

If ...as the primacy of perception requires, we call what we perceive "the world," and what we love "the person," there is a type of doubt concerning man, and a type of spite, which becomes impossible.... We weight the hardihood of the love which promises beyond what it knows, which claims to be eternal when a sickness, perhaps an accident, will destroy it... But it is true, at the moment of this promise, that our love extends beyond qualities, beyond the body, beyond time, even though we could not love without qualities, bodies, and time. (PrP in PoP 26-27; cf. AD 142 and ch. 5)

And here surfaces the clue which unifies Merleau-Ponty's developmental argument against idealism and empiricism with the counterproofs from pathologies and which, when the three developmental stages are kept distinct, would provide a condition for the possibility of a communicative and existential ethic: since I am from birth disempowered, and because this original sympathy is never fully suppressed in individuation, the realms of affectivity and pathology can bring about regression from "selfless" adult love to the real loss of identity and the failure in sustaining genuine intersubjectivity (RO in PoP 155). If love is MerleauPonty's paradigm of adult sympathy, then we can understand why he also chose Wallon's study of child sympathy-and not as did Lacan, Wallon's account of jealousy-as the founding term of self-identity and alterity. The attitude of primordial sympathy presupposes the affective equilibrium of reciprocity and equality. Reciprocity is thematically recovered in an equilibrium of a dialogue and deliberately won in loving.

The identification of the child with its specular image parallels similar identification with others (RO in PoP 135). Because the reduction of the specular stage of human development never results in the intellectual and affective differentiation of my visual body from my introceptive body, sympathy in syncretic sociability of children founds epistemology, affectivity, and allows for the ethic of love and dialogue. The adult reappropriation of sympathy remains the founded pole, while primordial sympathy plays the affective-epistemological role parallel to the founding function of perception in acts of cognition. The affective significance of our interest in the specular image is, thus, the key to Merleau-Ponty's phenomenology of love and dialogue (RO in PoP 137). The belief of the child that the mirror-image is its double never wholly 
leaves the adult. The child's affective tie to the specular drama enters operative intentionality as it functions in adult cognition and deliberation (RO in PoP 138). A total reduction of the specular-ego would be possible only if human relations were free of emotional risks. But risk-free love and dialogue constitute a fiction imagined by thetic cogito. "[S]ince the imagereflection is unstable, the operations that constitute it involve not only the intelligence proper but, rather, all the individual's relations with others" (ibid.).

To illustrate: the case of 'transitivism' reflects how an indistinction between the ego and the alter which is typical in the syncretic sociability of children can reappear in adult relations of love and in pathologies. Transitivism represents a loss of relative equilibrium between ego-identity and alterity. It consists "in attributing to others what belongs to the subject" (RO in PoP 148). What happens to us influences our view of others. Children often impute their own attitudes to the alter. In cases of transitivism, two personalities of children can become wholly nondifferentiated (RO in PoP 149). Their perspectives in space and time, the apprehension of the relations between words and things, symbols and the model, the inner and the outer likewise remain indistinct. The child can identify different parts of the body but will not differentiate between its own hand and that of the alter. Picasso's cubist art and Derrida's deconstructed being-in-the-world will be more immediately accepted by the child than by the adult, because these notions have the character of the child's world (RO in PoP 150). If sympathy in the stage of syncretic sociability manifests indistinctness between the self and the alter, then an adult love threatens a relapse to such non-differentiation. This threat delivers good suffering; the pathos of suffering retains the promise that sympathy is possible, that internal weakness which binds me to others can be reappropriated ethically.

"The crisis at three years" can't affect the differentiation of the self and the alter through the total reduction of syncretic sociability. This crisis sets the stage for adult love and hatred. Around the age of three, the child begins to adopt his own stance towards others and the world. Only now begins the saga of Sartre's dialectic of alienating gazes: the child changes his reactions to alter's gaze (RO in PoP 152f.). Merleau-Ponty argues that love is not exemplified by mutual attempts at capturing the freedom of the alter.14 During the crisis at three the ego doubles itself with an "ego in the eyes of the other" (RO in PoP 153). The child is annoyed and disturbed in his activity by the alien gaze. The child finds himself to be also what others

14 Cf. Mary Rose Barral, Merleau-Ponty: The Role of the Body-Subject in Interpersonal Relations (Pittsburgh: Duquesne UP, 1965), p. 160f. "Self and Other: Communication and Love," Review of Existential Psychology and Psychiatry XVIII, 1,2 \& 3 (1982-83): 155-180. 
see of him. The crisis results in the distanciation of syncretism and the generalization of the specular image.

Merleau-Ponty argues that we meet the primordial sense of sympathy and even transitivism during adulthood (RO in PoP 154). Specific limiting situations in adult life will evoke the latent indistinction between the self and the alter. The fright of insecurity reoccurs not only within Cartesian anxiety but inevitably in love and dialogue. The age of three does not resolve the risks which mature relations solicit. "Transitivism, which has been surpassed in the realm of immediate daily life, is never surpassed in the realm of feelings" (RO in PoP 155).

We should note what is important in Merleau-Ponty's analysis. The first three years of human development set the original theater for adult love and conflict. The internal weakness of primordial sympathy can't be apodictically overcome. The ontology of sympathy stipulates that I can be reconciled to that interior tie which bonds me with the alter without pathology and overt conflict. The phenomenology of love and dialogue argues that I ought to take up my primordial weakness and make it the strength of my adult relationships. The phenomenology of sympathy does not privilege the child, nor does it explain adult behavior by pathologies. The cases are used as counter-factuals which depict operative intentionality and sympathy as the horizon and the conditions of thematic intentionality in sustaining self-identity and alterity.

\section{TOWARDS A COMMUNICATIVE AND EXISTENTIAL ETHIC}

Just as Merleau-Ponty never wrote a phenomenology of sympathy, so also he did not develop a moral theory and an existential ethic. The following reconstruction is my programmatic proposal.

We must inquire whether and how the reappropriation of primordial affect of sympathy becomes justified in deliberate human relations. My distinction of the three developmental stages suggests that the cognitive and normative character of dialogic reciprocity can be conceived neither as a regression to nor an extension of affective sympathy. Affects are necessary but not sufficient as rational and existential grounds. Affective solidarity of lifeworld provides a resource of individual and group identities and the pool of background assumptions. Life-world contains a communitarian perspective but sustains, on its own, neither the normatively moral point of view nor a decisively responsible living. Given the affective, lifeworld primacy of sympathy in human ontogenesis and adult relations, in what sense can we speak of its moral and existential primacy?

I sketch three steps in which Merleau-Ponty's reply could be reconstructed: $1 /$ The disempowerment of the ego provides the descriptive, hermeneutic, and rational justification for the form of communicative and the mode of existential ethics. Morality and 
existential ethic are to compensate for vulnerable, decentered human identity. This compensation for affective risks in the core of identityformation stabilizes intersubjectivity on normative justice and concrete solidarity. 2/ Merleau-Ponty's critique of terror and of the Communist Party cannot but assume a counterfactual form of life, the ideal communication community, on the one hand, and non-authoritarian, open, and unrepressed existential identity on the other. 3/ The dialectic of discourse and power does not sustain postmodern evidence for the ubiquity of power in lifeworld and identity-formation: 15

1. Let me read Merleau-Ponty's view of mimesis and phenomenological contribution to communicative and existential ethics against Horkheimer's and Adorno's Dialectic of Enlightenment:

The ratio which supplants mimesis is not simply its counterpart. It is itself mimesis: mimesis unto death. The subjective spirit which cancels the animation of nature can master a despiritualized nature only by imitating its rigidity and despiritualizing itself in return. ... Men had to do fearful things to themselves before the self, the identical, purposive, and virile nature of man, was formed, and something of that recurs in every childhood. 16

Adorno's mimetic logic, under the figure of homeless Odysseus, depicts both human ontogenesis and rational life-forms in the service of repression of inner and oppression of outer nature. The conquest of outer nature already despiritualizes human inner nature. Rational forms of life do not sustain embodied intersubjectivity but imitate the dead outer nature. Human development is an iron cage of self-destructive identity, a development unto death. If there be any positive role for critique, then it could employ conceptuality only paradoxically as a negative dialectic. If there be any emancipation, then it must be postponed to the aesthetic other of ratio. Because Adorno's critique is normatively unjustified, his aesthetic utopia of unrepressed non-identity is performatively selfcontradictory: Adorno uses experience, understanding, and judgment to

$15 \mathrm{Cf}$. another reconstruction by Kerry $\mathrm{H}$. Whiteside, Merleau-Ponty and the Foundation of an Existential Politics (Princeton: Princeton UP, 1988). In ch. 10. Whiteside compares Merleau-Ponty with Michael Walzer, John Rawls, and Michel Foucault.

16 Max Horkheimer /Theodor Adorno, Dialectic of Enlightenment, trans. John Cumming (New York: Continuum, 1987), Pp. 57, 33. 
undermine the descriptive, hermeneutic, and rational evidence of claims. 17

Against Adorno's mimetic logic Merleau-Ponty's non-representational description of mimesis can be maintained and stabilized in post-traditional forms of life on the deliberative basis of autonomous selfdetermination and existential self-realization. One, the moral point of view compensates for the fragile human identity by appealing to formal normative presuppositions: in ongoing discourses, the ideal communication conditions of symmetry (reciprocity and equality) between the ego and the alter must be fulfilled if validity-claims are rationally justified. Two, an existential ethic sustains identity-claims only in relations of openness to the concrete other. Thus, universal justice and solidarity in the moral point of view and also concrete applications of normative criteria presuppose the formal counterfactual conditions of that life-form which admits of non-authoritative, open, and unrepressed identity for whose fragility morality and existential ethics compensate. 18

17 Cf. my "Habermas On Communicative Reason and Performative Contradiction," New German Critique 47 (1989): 163-92 and "Jürgen Habermas at 60" Philosophy and Social Criticism (forthcoming).

18 Cf. Jürgen Habermas, Moralbewußtsein und kommunikatives Handeln (Frankfurt a/M: Suhrkamp Verlag, 1983); "Gerechtigkeit und Solidarităt: Eine Stellungnahme zur Diskussion aber 'Stufe 6," in: Wolfgang Edelstein and Gertrud Nunner-Winkler, eds., Zur Bestimmung der Moral: Philosophische und sozialwissenschaftliche Beiträge zur Moralforschung (Frankfurt a/M: Suhrkamp Verlag, 1986), pp. 291-318; "Moralität und Sittlichkeit. Treffen Hegels Einwånde gegen Kant auch die Diskursethik zu?" in: Wolfgang Kuhlmann, ed., Moralitat und Sittlichkeit: Das Problem Hegels und die Diskursethik (Frankfurt: Suhrkamp Verlag, 1986), pp. 1637.

Habermas notes the aporias of Adorno's mimetic logic: for Adorno the concept operates as a polarity between object and subject. The emancipatory capacity of reason remains hidden. Adorno cannot recognize communicative competence as the condition of the possibility of critique and emancipation. The polarized logic of inner and outer nature shows only objectified functions of language but fails to account for its commencement in life-world. Mimesis is the irrational other of rationality. In order to effect a unity of mimesis and reason in the basis of language, Habermas proposes a paradigm shift. The cultural-social realm is constituted both by communicative and objectifying reason, life-world and system. The utopian perspective enters communicative rationality itself. Unconstrained intersubjectivity is that counterfactual which can be won by communicative reason because of its linguistic nature. Jürgen Habermas, Die Neue Unubbersichtlichkeit [Frankfurt/M: Suhrkamp Verlag, 1985], "Ein Interview mit der New Left Reoiew," esp. p. 221; The 
Descriptive, hermeneutic, and rational evidence for the possibility of communicative and existential ethics lies in a lifeworld-notion of mimesis as disempowerment of the ego.

First, descriptive evidence shows that identity claims of the ego and the alter are formed through embodied intersubjectivity. Mimesis does not represent a development out of the aporias between the inner and outer nature. These aporias are only later constructs. The ego and the alter qua embodied intersubjectivities are equally and reciprocally disempowered. Merleau-Ponty's evidence counters the descriptive failures common to Hegel, Adorno, Kojeve, Sartre, Lacan, and Foucault that lead these thinkers to various formulations of an ethic based on higher-subjectivity, negative dialectic, violence, gaze or nihilation, unconscious desire, and disciplinary bio-power. 19

Second, hermeneutic evidence depicts lifeworld as the horizon of understanding and freedom. Not only identity-claims but also free will is embedded in lifeworld. Merleau-Ponty shows that freedom is neither an unmotivated leap nor a determined cause. He situates freedom between culture and an existential motivation of the agent. The linguisticality of lifeworld provides the sedimented meanings for the reproduction of cultural, social, and personal interaction. Descriptive and hermeneutic evidence thematize embodied intersubjectivity as incarnate in social time and historical space. Lifeworld offers cumulative evidence: ego and alter are equally and reciprocally disempowered; they can neither objectify their linguistically formed identities nor originate life-projects ex nihilo.

Third, rational evidence is available in discourse. Communication inherits but maintains and stabilizes the descriptive and hermeneutic evidences of disempowerment. While one attains identity only in lifeworld, deliberate identity-and validity-claims originate in a public sphere. Rational evidence for the possibility of communicative and existential ethics is a judgment of the fact that I cannot know myself without the point of view of intersubjectivity. The public sphere of dialogue is the stabilizing condition of all truth- and value-claims. While hermeneutic evidence provides the communitarian basis of truth and objectivity in sedimented meanings, rational evidence is necessary for the public defensibility of values. 20

Philosophical Discourse of Modernity: Twelve Lectures, trans. Frederick Lawrence [Cambridge: MIT P, 1987], lecture V.)

19 This evidence is an option to postmodernism, a resource for resolving what Seyla Benhabib calls feminist identity-crisis. Cf. * below and my "Identity and Power: $A$ Contribution to the Debate between Postmodernism of M. Foucault and Critical Modernism of J. Habermas," Filozoficky casopis, written and published in Czech (Praha: Academy of Sciences, forthcoming in 1991).

20 Cf. Whiteside, Merleau-Ponty, p. $306 f$. 
2. Merleau-Ponty's critique of distorted communication presupposes fourth type of evidence, i.e. normative counterfactual. Just as in his diagnosis of Schneider, so also in his critique of the revolutionary terror and of the Communist Party, counterfactual evidence must satisfy the objectivity of critique and the plausibility of the proposed cure.

Merleau-Ponty transforms the meaning of revolutionary violence into non-Communist leftism: non-partisan and non-ideological, communicative and existential praxis. In his critique of the equivocal character of the Communist Party and its authority, he prefigures Habermas's communicative ethics (AD 209 ff.). He offers a phenomenologically founded social critique and a critically chastened existentialphenomenology: "Thus Marxism needs a theory of consciousness which accounts for its mystification without denying it participation in truth" (AD 41,45). 21

The stand-point of social critique remains fallibilist: "Truth itself is then conceived as a process of indefinite verification..." (AD 53). Critical phenomenology becomes a "permanent interrogation," "the genealogy of truth," and an existentially intensified social praxis (AD 57). Critical posture embodies "a praxis of a superior degree"--superior to the arbitrary revolutionary violence and to the positivism of the Communist Party (AD 50). Existential and social praxis has hope; but this hope is not a material utopia but a mode of existence. Hope retrieves the conditions of reciprocity and equality in ongoing appropriations of mutual love and dialogue:22

There is a dialectic only in that type of being in which a junction of subjects occurs, being is not only a spectacle that each subject presents to itself for its own benefit but which is rather their common residence, the place of their exchange and of their reciprocal interpretation. (AD 204)

Communicative and existential ethics requires--besides the descriptive, hermeneutical, and rational evidence for its possibility-also the performatively ascertained conditions of symmetry, equality, and

21 Habermas consoles by "non-Communist leftism" leftists who are disenchanted after the November 1989 events in Central Europe (cf. his Die nachholende Revolution: Kleine Politische Schriften VII (Frankfurt a/M: Suhrkamp Verlag, 1990), p 188ff.

22 Cf. Václav Havel's "existential revolution" (cf. his Moc bezmocnych [Praha, 1978], in German, Versuch, in der Wahrheit zu leben, trans. Gabriel Laub [Hamburg: Rowohlt, 1990], chaps 20-22) and my "Vertical Identity as a Critique of Power: Kierkegaard, Lévinas, and Havel" (presented in Czech, Praha: Charles' University, 11 April 1990); cf. section 3 below. 
reciprocity in discourse. Performative contradiction falsifies this requirement. Contradiction occurs when a critic communicates without normative evidence and counterfactual basis. It is self-contradiction because the critic undermines the conditions that pertain to her own existence. The critic uses experience, understanding, judgment, and deliberation to jettison all types of evidence.

Contrary to legitimate postmodern sensitivity to pathological modernity, communicative and existential ethics calls not for less but more evidential rationality, not for the death of an already disempowered identity but for an intensification of one's responsible existence through receptivity to the other. Ubiquity of power, totality, and revolutionary terror are problems only for the Cartesian, scientistic, Party- and Führer-oriented cogito but not for the self which relates to itself and alter as autonomous but disempowered subjectivities. Communicative and existential counterfactual operates in any will to discourse intensified through experience, understanding, judgment, and deliberation vis-à-vis its own powerlessness. We are not powerless because I or the alter could not act from the will to power. We are disempowered insofar as we will to discourse.

Four levels of evidence have strength in the phenomenologically grounded existential self. Discourse originates, first, in embodied intersubjectivity; second, in the cultural, social, and personal lifeworld; third, in the publicly formed identity and validity claims; and, fourth, through the will oriented to intersubjectivity, lifeworld, and the public sphere. 23

23 Merleau-Ponty's post-Husserlian account of embodied intersubjectivity and lifeworld fills the lacuna in Habermas's communicative ethics and could reply to recent feminist and communitarian critiques of its formalism. (Seyla Benhabib, Critique, Norm, and Utopia: $A$ Study of the Foundations of Critical Theory [New York: Columbia UP, 1986]; Benhabib and Drucilla Cornell, eds., Feminism as Critique IMinneapolis: $U$ of Minnesota P, 1987]. Michael J. Sandel, Liberalism and the Limits of Justice [Cambridge: Cambridge UP, 1982]. Alasdair Maclntyre, After Virtue [Indiana: U of Notre Dame P, 1981].)

Benhabib, critically following Gilligan's attack on Kohlberg's moral theory, notes that Habermas develops a formal communicative ethic of the generalized self but lacks an ethic of the concrete self, the ethic of solidarity and friendship. She calls for integrating both ethical perspectives: "The perspective of the generalized other urges us to respect the equality, dignity, and rationality of all humans qua humans, while the perspective of the concrete other enjoins us to respect differences, individual life-histories and concrete needs" (Benhabib, Critique, p. 351). I suggest to complement the formal counterfactual--Habermas's validity claims of the ethic of communication-with descriptive, hermeneutical, rational, and critical-existential evidence. Phenomenology of sympathy 
3. Mimesis inherited and stabilized by communicative and existential ethics requires an intensification of the concrete self through will against power. Will against power, not will to discourse counters any claimed primacy of will to power in the formation of post-traditional identities and life-forms. 24

Will against power maintains the primordial situation of disempowered identity in the sense of vertical transcendence, i.e., an enabling asymmetry of that other which confronts totality in the very identity-formation. If the ideal symmetry conditions of communication are to be fulfilled concretely, then such a check on self-deceptive willing is called for. The check is, however, provided not by one's positive willing but by one's openness to that asymmetrical claim of the other which unmasks power-asymmetries in validity-and identity-claims. 25

Merleau-Ponty's phenomenology of sympathy does not envision vertical transcendence and essential asymmetry, but it already questions the descriptive accuracy of any ontological egology. Merleau-Ponty's disempowered ego assumes the background of the ideal symmetry conditions of reciprocity, but this symmetry does not preclude, rather presupposes, the asymmetrical conditions of its possibility. My third step thematizes what communicative ethics requires to sustain itself existentially: my argument moves from a symmetrical disempowerment of the ego on the basis of the projected ideal communication community to the asymmetrical conditions of the possibility of this ideal community in radical otherness and vertical transcendence. 26

From a systemic standpoint my good will that harnesses life-world imperatives towards the other seems utopian. It appears utopian, since will to discourse-on its own and even under the conditions of unconstrained communication-cannot guarantee to itself that it would not emerge as will to power. For this reason, the quasi-transcendental standpoint in communicative symmetry must be transformed through the vertical transcendence of enabling asymmetry conditions: my identity is constituted in the claim of the other, not through my good will.

inhabits the gap between the generalized other of communication and the concrete self. While descriptive evidence cannot replace normative counterfactual in critique, it is also true that communicative ethics cannot be divorced from lifeworld and existential identity-formation.

24 Cf. my review of Essays in Hermeneutics and Critical Theory by Rüdiger Bubner in Auslegung (January 1990).

25 Cf. my "Jürgen Habermas at 60" and n. 22 above.

26 Cf. Emmanuel Lévinas, Totality and Infinity: An Essay on Exteriority, trans. Alphonso Lingis (Pittsburgh: Duquesne UP, 1969) and Richard A. Cohen, ed., Face to Face with Levinas (Albany: SUNY, 1986), "Dialogue with Emmanuel Lévinas." 


\section{Conclusion}

Merleau-Ponty legitimately privileges operative sympathy. This sympathy founds and sustains the developmental stage of latent alterity and self-identity in ontogenesis and adulthood.

His counterfactual evidence depicts how ordinary and pathological failures in sustaining self-identity require the horizon of pre-personal sympathy as the distinct condition of their possibility. Sympathy, whether primordial or deliberate and thematic, presupposes the absence of differentiation between the self and the alter. Sympathy must be the more originary attitude than that of jealousy or cruelty. Perception and primordial sympathy, contrary to idealism and empiricism, do not consist of fragmentary qualities but operate as the horizon of co-existence with others. Jealousy, already present in the attitude of children but perfected in adult relations, can be understood only as a developmental 'fall' into non-differentiation and supplementation of self-identity by the fragmented qualities of the desired object. Sympathy cannot be primarily a dialectic of the desire to be desired, since such a dialectic begins with a phenomenology that illegitimately privileges fragmentary self-identity and alterity. Merleau-Ponty argues that love, unlike jealousy, is integral, because in sympathy one loves the total person, not merely alienated, atomized and fragmented qualities which could be shared by a third one.27

I asked in what sense can the thesis of the primacy of sympathy meaningfully speak for the primacy of adult love. If the former primacy is the phenomenology of lifeworld, the latter comprises a moral and existential issue. The primacy of love and will to discourse is held as the moral imperative of the symmetry conditions of reciprocity and equality. But will to discourse demonstrates also the impossibility of the total reduction to the conditions of its own possibility. Any good will could emerge as will to power. This weakness is remedied neither by assuming the ubiquity of will to power nor by a postmodern unwillingness to be a self. 28 Will to discourse meets its own possibility in the enabling asymmetry condition of willing against power, in the claim of radical otherness.

27 He argues this point in "Metaphysics and the Novel," SN, pp. 36-40 against the backdrop of Simone de Beauvoir's L'Invitée (Paris: Gallimard, 1956). See also PrP in PoP 26.

28 Søren Kierkegaard clarifies asymmetrical conditions as will against despair: willing to be a self before the radical otherness of God. Despair is a form of will to power. Cf. his The Sickness Unto Death, trans. Howard V. Hong and Edna H. Hong (New Jersey: Princeton UP, 1980). 
This conclusion strengthens the phenomenology of sympathy and its equal founding primacy in ontogenesis and adulthood. It legitimizes neither the death of the subject nor the thesis of the ubiquitous asymmetry of a will to power. Neither the four-fold evidence furnished by social phenomenology nor the vulnerability of identity stabilized in communicative ethics nor the weakness of my will to discourse checked by the verticality of existential ethics warrant the postmodern ethic of anarchy, anti-humanism, and power.

From Merleau-Ponty, we have learned that such ethics cannot be descriptively, hermeneutically, and rationally validated. He points out that human development occurs primarily in disempowerment and only secondarily through will to power. The ubiquity and primacy of will to power as a thesis, unlike communicative ethics, do not provide any measure of falsifiability. If the thesis is asserted at will, then what is arbitrarily asserted can be discursively criticized or denied. We were brought from the formal quasi-transcendental conditions of symmetry to vertical transcendence. But will against power does not flee finitude of powerlessness; here one learns and acts through the claim of radical otherness and through suffering. 29

\section{NOTE}

- I wish to acknowledge Patricia Huntington, James L. Marsh, Merold Westphal, Jürgen Habermas, and the editors of Auslegung for their critical comments on the earlier versions of this paper. The paper was presented and discussed during my Fulbright year in Germany in Jürgen Habermas's Monday night Colloquium (Frankfurt a/M: JGW Universität, Jan 1990). A sequel to this paper, "Merleau-Ponty On Taking The Attitude of the Other," appears in The Journal of the British Society for Phenomenology Vol. 22, No. 1 (Jan 1991).

29 On the notion of suffering, cf. thinkers like Metz, Lamb, Gadamer, Lévinas, and Kierkegaard: Johannes Baptist Metz's contribution to Habermas- Festschrift, in: Axel Honneth, Thomas McCarthy, Claus Offe and Albrecht Wellmer, eds., Zwischenbetrachtungen: Im Prozeß der Aufklärung (Frankfurt/M: Suhrkamp Verlag, 1989), 733ff; Matthew L. Lamb, Solidarity With Victims: Towards a Theology of Social Transformation (New York: Crossroads, 1982); Hans-Georg Gadamer, Truth and Method (New York: Crossroads, 1975), 320; Søren Kierkegaard, Concluding Unscientific Postscript, trans. David F. Swenson and Walter Lowrie (Princeton: Princeton UP, 1941), chap. IV, sec. II, A, \# ii, 386ff; for Lévinas, cf. nn26, 22 above. 